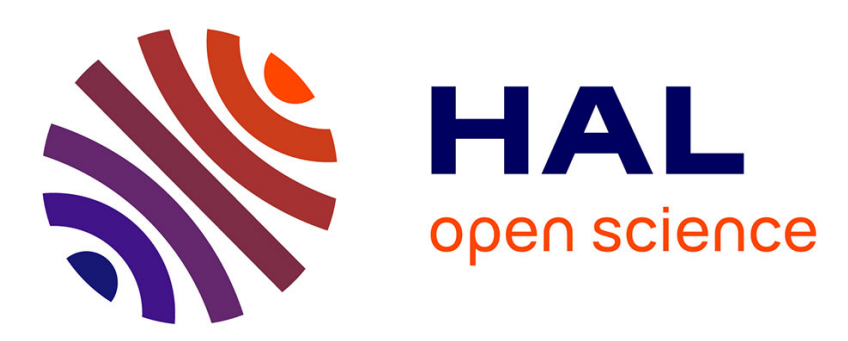

\title{
Decomposition kinetics and organic geochemistry of woody debris in a ferralsol in a humid tropical climate
}

Kenji Fujisaki, Anne-Sophie Perrin, Mohammed Boussafir, Sébastien Gogo, Max Sarrazin, Michel Brossard

\section{- To cite this version:}

Kenji Fujisaki, Anne-Sophie Perrin, Mohammed Boussafir, Sébastien Gogo, Max Sarrazin, et al.. Decomposition kinetics and organic geochemistry of woody debris in a ferralsol in a humid tropical climate. European Journal of Soil Science, 2015, 66 (5), pp.876-885. 10.1111/ejss.12277 . hal01269312

\section{HAL Id: hal-01269312 \\ https://hal.science/hal-01269312}

Submitted on 24 Nov 2016

HAL is a multi-disciplinary open access archive for the deposit and dissemination of scientific research documents, whether they are published or not. The documents may come from teaching and research institutions in France or abroad, or from public or private research centers.
L'archive ouverte pluridisciplinaire $\mathbf{H A L}$, est destinée au dépôt et à la diffusion de documents scientifiques de niveau recherche, publiés ou non, émanant des établissements d'enseignement et de recherche français ou étrangers, des laboratoires publics ou privés. 


\title{
Decomposition kinetics and organic geochemistry of woody debris in a ferralsol in a humid tropical climate
}

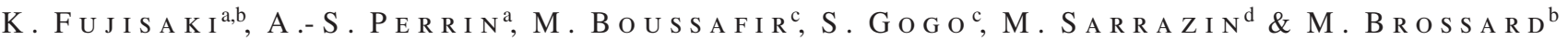 \\ ${ }^{\mathrm{a} C e n t r e ~ T e c h n i q u e ~ I n t e r p r o f e s s i o n n e l ~ d e s ~ O l e ́ a g i n e u x ~ e t ~ d u ~ C h a n v r e ~(C E T I O M), ~ E t a b l i s s e m e n t ~ P u b l i c ~ L o c a l ~ d ' E n s e i g n e m e n t ~ e t ~ d e ~}$ \\ Formation Professionnelle Agricole (EPLEFPA) de la Guyane, Savane Matiti, BP 53, 97 355, Macouria, Guyane Française, France, bIRD \\ (Institut de Recherche pour le Développement), UMR 210 Eco\&Sols (CIRAD, INRA, IRD, Montpellier SupAgro), Bâtiment 12, 2 Place \\ Viala, F-34060, Montpellier Cedex 02, France, ' ISTO, UMR 7327 du CNRS/INSU/BRGM/Université d'Orléans, $1 A$ Rue de la Férollerie, \\ 45071, Orléans, France, and ${ }^{\mathrm{d}}$ Laboratoire des Moyens Analytiques (LAMA), IRD - US122, Route de Montabo, F-97323, Cayenne Cedex, \\ Guyane Française, France
}

\begin{abstract}
Summary
Large inputs of woody debris to soil can improve the soil. We examined the fate of woody debris buried in soil after fire-free forest conversion to cropland in French Guiana. We measured the mass loss of woody debris $>4 \mathrm{~mm}$ on five sampling dates for 4 years after deforestation. Composition of the organic matter of woody debris was analysed with Rock-Eval pyrolysis, which enabled us to distinguish a labile carbon pool $\left(\mathrm{C}_{\mathrm{lab}}\right)$ and a resistant carbon pool $\left(\mathrm{C}_{\mathrm{res}}\right)$. Decomposition of woody debris followed a first-order function with a half-life of 17.6 months. During the decomposition of woody debris $>4 \mathrm{~mm}$, the C:N ratio, hydrogen index (HI) and pyrolysed carbon below $400^{\circ} \mathrm{C}$ (R400) decreased, suggesting that decarboxylation and dehydrogenation of woody debris occurred. Both $\mathrm{C}_{\text {lab }}$ and $\mathrm{C}_{\mathrm{res}}$ stocks decreased with time, but the decrease in $\mathrm{C}_{\mathrm{lab}}$ was faster. There was little humification of the debris and no long-term biogeochemical preservation of a woody debris fraction, which accords with the first-order decay observed. We conclude that the benefits of ligno-cellulosic inputs for soil organic carbon contents in a tropical humid climate occur during the first year following deforestation.

\section{Résumé}

Les apports massifs de débris de bois au sol peuvent améliorer le sol. Nous avons examiné sur un site en Guyane le devenir de débris de bois enfouis dans le sol, suite à la conversion sans brûlis de forêt en cultures. Nous avons mesuré le stock des débris de bois $>4 \mathrm{~mm}$ jusqu'à 4 années après déforestation. Les transformations de la matière organique des débris ont bois ont été analysées par la pyrolyse Rock-Eval, nous permettant de distinguer un compartiment de carbone labile $\left(\mathrm{C}_{\mathrm{lab}}\right)$ et un compartiment de carbone résistant $\left(\mathrm{C}_{\mathrm{res}}\right)$ dans ces débris. La décomposition des débris de bois suit une décroissance exponentielle de premier ordre, avec une demi-vie de 17,6 mois. Durant la décomposition des débris, le rapport C/N, l'indice d'hydrogène (HI) et le carbone pyrolysé avant $400^{\circ} \mathrm{C}(\mathrm{R} 400)$ diminuent, suggérant des processus de décarboxylation et déshydrogénation qui se mettent en place rapidement après l'enfouissement des débris. Les stocks de $\mathrm{C}_{\mathrm{lab}}$ et $\mathrm{C}_{\mathrm{res}}$ diminuent tous deux au cours du temps, avec une cinétique plus rapide pour $\mathrm{C}_{\mathrm{lab}}$. Ces résultats indiquent une faible polymérisation de la matière organique des débris, et une absence de préservation biogéochimique d'une partie des débris, en accord avec la décroissance exponentielle observée. Cette étude suggère que les bénéfices des amendements ligno-cellulosiques pour la matière organique des sols sont de courte durée en milieu tropical humide.
\end{abstract}

\section{Introduction}

Organic matter turnover in soil has received much attention for decades because it is the most important terrestrial reservoir of organic carbon (Jobbágy \& Jackson, 2000). Decomposition of organic matter releases nutrients for plants and plays an important role in the behaviour of carbon stored in the soil (Powlson

Correspondence: M. Brossard. E-mail: michel.brossard@ird.fr Received 19 June 2014; revised version accepted 1 April 2015 etal., 2011). In humid tropical conditions, temperatures and large amounts of rain, in addition to leaching where the soil is porous, lead to degradation and rapid mineralization of organic matter. Indeed, in the forest soil of Amazonia, decomposition of organic matter inputs produces low-molecular-weight compounds, which are leached rapidly or redistributed laterally in the soil (Cerri \& Volkoff, 1987).

Human activities (deforestation, fires and intensive cultivation) can affect the soil carbon dynamics of Amazonian ecosystems (Fujisaki et al., 2015). Deforestation in Amazonia results in general 
from the burning of biomass, but fire-free alternatives have been developed to reduce environmental damage from deforestation. These fire-free systems produce large amounts of woody residues from the shredding of vegetation. Woody residues reduce soil erosivity and improve short-term physical and chemical properties of soil. The increase in soil bulk density is less than with slash-and-burn methods (Comte et al., 2012; Perrin et al., 2014), and concentrations of plant nutrients increase (Comte et al., 2012). Nevertheless, the mass of woody debris could decrease quickly and its benefits might be short lived. Davidson et al. (2008) reported that the carbon stock from the litter layer decreased dramatically in less than 2 years in a chop-and-mulch system. Soil amendment with ramial wood chips leads, in general, to an increase in soil organic matter content (Barthès et al., 2010); however, to our knowledge specific studies on the decomposition of woody debris in soil and its contribution to the soil carbon stock are still lacking for a humid tropical climate.

When plant debris is incorporated into soil, leaching, mineralization and biological and biochemical fragmentation can occur (Swift et al., 1979). In parallel with these mechanisms of decomposition, parts of the plant structures might be humified; macromolecules are synthesized by condensation reactions, and nitrogen enrichment occurs (Andreux \& Meunier-Lamy, 1994).

Classical approaches for qualitative studies of litter humification are based on a broad spectrum of physico-chemical acid and or alkaline extractions (Pansu \& Gautheyrou, 2006). However, considering the processes involved in the decomposition sequence, and in particular the alteration of the molecules, their microbial, enzymatic or abiotic neoformation all occur at the same time (Andreux \& Meunier-Lamy, 1994; Almendros, 2008). Therefore, extractive techniques are not always appropriate and new approaches may have to be developed using the methods of organic geochemistry. Rock-Eval pyrolysis was developed initially to study hydrocarbons and kerogen from sedimentary rocks (Espitalié et al., 1985). Recently, it has been shown that Rock-Eval pyrolysis could provide valuable information about the organic matter composition of soil and sediments (Disnar et al., 2003; Delarue et al., 2011; Carrie et al., 2012; Saenger et al., 2013). Rock-Eval pyrolysis does not require sample pretreatment as for pyrolysis GC-MS, and it includes a stage where organic matter is pyrolysed in an inert atmosphere, whereas thermogravimetric analysis with differential scanning calorimetry (TG-DSC) is done in an oxygenated atmosphere.

We aim to define the decomposition kinetics and geochemistry of woody debris buried in soil over time in the context of fire-free forest clearance in Amazonia by mass loss assessment coupled with Rock-Eval pyrolysis. We hypothesize that given the biogeochemical nature of woody debris in tropical humid forests, much of that produced during forest clearance could be preserved or humified and might lead to carbon storage in soil. We also evaluated Rock-Eval pyrolysis to assess the decomposition of organic matter over time.

\section{Materials and methods}

\section{Study site}

The experimental site is in French Guiana $\left(5^{\circ} 17^{\prime} 55^{\prime \prime} \mathrm{N} / 52^{\circ} 55^{\prime}\right.$ $01^{\prime \prime} \mathrm{W}$ ). The climate is wet humid tropical (Ami type in Köppen-Geiger classification). The mean annual temperature is $27.3^{\circ} \mathrm{C}$ and mean annual precipitation is $2770 \mathrm{~mm}$, with a dry season from mid-August to mid-November. The soil is a 'ferralitisol meuble kaolinitique jaune' (AFES, 2009) or Hyperferralic Ferralsol (IUSS Working Group, 2007) with a sandy-clay texture and a porosity that favours vertical drainage. The main soil characteristics to $30-\mathrm{cm}$ depth are summarized in Table 1.

Native forest was cleared over an area of 2 ha in October 2008. Trunks and stems of diameter less than $15 \mathrm{~cm}$ (corresponding to the undergrowth) were chopped with a vertical axis mulcher with chains mounted on a 20-t wheeled excavator that produced woody debris between 10 and $30 \mathrm{~cm}$ in length. The resulting chopped biomass represents about $3-13 \%$ of the total standing biomass (Perrin et al., 2014). Timber and larger trunks were removed and stacked outside the study area. In December-January 2009, the soil was limed $\left(1 \mathrm{tha}^{-1}\right.$ of crushed limestone and $0.45 \mathrm{tha}^{-1}$ of powdered dolomite), tilled with a disk harrow to 20 -cm depth and cover crops were sown (a mixture of grass and legumes). In October 2009, large woody debris and cover crop residues were chopped to a maximum length of 5-7 cm with a forestry mulcher mounted on a self-propelled wheeled machine (Plaisance VT300, Montigny, France), and incorporated into the soil to about $10-\mathrm{cm}$ depth. The soil was then cultivated to grow grass and annual crops, which were planted in December 2009. Three crop systems were established:

Table 1 Physical and chemical properties of the soil's surface layer before forest clearing at the Combi site

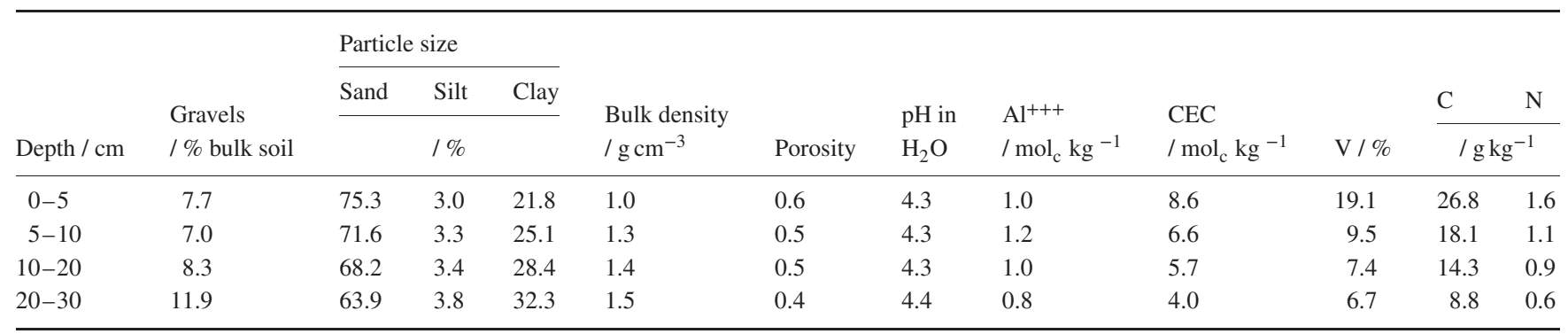

For $\mathrm{pH}$ measurement, soil: water ratio $=1: 2.5$.

$\mathrm{CEC}=$ cation exchange capacity $\mathrm{V}=$ base saturation .

Modified from Perrin et al. (2014). 
Table 2 Number of samples analysed

\begin{tabular}{lll}
\hline & $\begin{array}{l}\text { Number of quadrats } \\
\text { or soil samples } \\
\text { collected }\end{array}$ & $\begin{array}{l}\text { Number of woody debris } \\
\text { samples analysed with } \\
\text { Rock-Eval and chemical methods }\end{array}$ \\
\hline October 2008 & 14 & 12 \\
November 2009 & 18 & 6 \\
April 2010 & 18 & 6 \\
November 2010 & 72 & 6 \\
November 2011 & 72 & 6 \\
November 2012 & 72 & 6 \\
\hline
\end{tabular}

Mass loss of woody debris was assessed with quadrats and from the soil samples collected. Woody debris samples analysed with Rock-Eval and chemical methods were selected randomly from the whole set of woody debris available at each date.

(i) grassland that was mowed twice a year, (ii) rotation of maize and soya beans with no tillage and (iii) rotation of maize and soya beans with disk tillage to $15-\mathrm{cm}$ depth. In the three systems, the soil was limed once a year in November with powdered dolomite $\left(1 \mathrm{tha}^{-1}\right)$. Four replicate plots $(10 \mathrm{~m} \times 20 \mathrm{~m})$ were set up for each system in a randomized complete block design. The complete management history is given in Perrin et al. (2014).

\section{Woody debris sampling and sorting}

Woody debris was sampled immediately after deforestation in October 2008 in 14 quadrats of $0.68 \mathrm{~m}^{2}$ area that were placed randomly in the deforested area. After establishment of the cropland, the woody debris that remained in the soil samples was separated from the mineral soil. The soil was sampled on five dates after crop harvests and before lime application: November $2009(n=18$ sampling points), April $2010(n=18)$, November $2010(n=72)$, November $2011(n=72)$ and November $2012(n=72)$ (Table 2). In November 2009 and April 2010 only three plots (one replicate block) were sampled, with six sampling points per plot, resulting in 18 sampling points. Given the considerable spatial variation in the distribution of woody debris, four blocks were sampled from November 2010. Soil cores (0.08-m diameter) were taken with a manual auger from four depths: $0-5,5-10,10-20$ and $20-30 \mathrm{~cm}$. From these soil cores, we determined the bulk density and the woody debris mass. Bulk density was calculated for all sampling dates, with the weight of each soil core corrected for soil moisture determined on a subsample dried at $105^{\circ} \mathrm{C}$ for 48 hours. Soil samples were air-dried and sieved at $2 \mathrm{~mm}$. Plant fragments $>2 \mathrm{~mm}$ were dried at $60^{\circ} \mathrm{C}$ for 72 hours and sieved at $4 \mathrm{~mm}$. Woody debris was sorted manually on the 4-mm sieve and weighed. The amount of woody debris, $S$, $>4 \mathrm{~mm}$ for each sample was calculated as:

$$
S=W \times E \times D_{b},
$$

where $S$ is the stock of woody debris in $\mathrm{tha}^{-1}, W$ is the woody debris content in the layer, $E$ is the thickness of the layer and $D_{b}$ its bulk density. For each sampling point, the values of $S$ for each of the four layers were summed to obtain the stock of woody debris in the $0-30 \mathrm{~cm}$ layer.

\section{Chemical analysis}

Carbon and nitrogen contents were measured on samples of woody debris. For October 2008, 12 samples were selected randomly from the 14 quadrats. For the next five sampling dates, six samples of woody debris were selected randomly for each date from the woody debris sorted into soil samples, which integrated the whole 0-30-cm soil layer for each selected point (Table 2). Woody debris samples were crushed finely prior to analysis, and their moisture content was measured by oven-drying at $105^{\circ} \mathrm{C}$ for 48 hours. Elementary analysis by dry combustion (Thermoquest NA 2100) gave total carbon $\left(\mathrm{C}_{\mathrm{dc}}\right)$ and nitrogen contents and the $\mathrm{C}: \mathrm{N}$ ratio of the woody debris samples. For the 12 samples from October 2008 , three replicates were analysed to assess the variability of aliquot samples. Standard errors for these samples did not exceed $8 \mathrm{~g} \mathrm{C} \mathrm{kg}^{-1}$. We calculated the carbon stock of woody debris in soil to $30-\mathrm{cm}$ depth from $\mathrm{C}_{\mathrm{dc}}$ and biomass stock.

As woody debris was separated from soil samples, it could include small mineral soil particles. Therefore, we determined organic matter contents $(\mathrm{OM})$ by 2 hours loss-on-ignition in an oven to $700^{\circ} \mathrm{C}$, and we could express results in units of organic compounds per unit of pure organic matter.

\section{Rock-Eval analysis}

The bulk composition of woody debris was determined by Rock-Eval (RE) pyrolysis on the same crushed samples that underwent chemical analyses (Table 2). Sample mass was about $50 \mathrm{mg}$. We used an RE6 pyrolyser (turbo model, Vinci Technologies ${ }^{\circledR}$, Nanterre, France). Rock-Eval pyrolysis has two steps: first, samples are pyrolysed in an inert $\mathrm{N}_{2}$ atmosphere (pyrolysis stage) at 200 to $650^{\circ} \mathrm{C}$, and a flame ionization detector (FID) and infrared (IR) cells detect compounds released by thermal decomposition of the organic matter. Second, the residual material is burned in an oxidation oven (oxidation stage) at $450-750^{\circ} \mathrm{C}$, and IR cells detect the oxygenated compounds released. For both stages the heating rate is $30^{\circ} \mathrm{C}$ minute ${ }^{-1}$. Five pyrograms are produced during Rock-Eval pyrolysis related to the release of hydrocarbons (HC) ( $\mathrm{S} 1$ and $\mathrm{S} 2$ pyrograms) and $\mathrm{CO}$ and $\mathrm{CO}_{2}$ (S3 pyrogram) during the pyrolysis stage, and $\mathrm{CO}$ and $\mathrm{CO}_{2}$ ( $\mathrm{S} 4$ and $\mathrm{S} 5$ pyrograms) are released during the oxidation stage. The indices HI (hydrogen index) and OI (oxygen index) are calculated from S2 and S3 pyrograms (pyrolysis stage), respectively. The $\mathrm{HI}$ is correlated with the $\mathrm{H}: \mathrm{C}$ ratio of the material, and $\mathrm{OI}$ is correlated with the $\mathrm{O}: \mathrm{C}$ ratio of the material. Total organic carbon (TOC) represents the sum of the carbon signal obtained from pyrolysis and oxidation. More information about the apparatus and Rock-Eval pyrolysis methodology is given in Espitalié etal. (1985), Lafargue etal. (1998) and Behar etal. (2001). The different values derived from the Rock-Eval pyrolysis are commonly called 'parameters' in the literature; however, in this paper we use the term 'variables'. 
Table 3 Variables calculated from Rock-Eval pyrolysis (adapted from Behar et al., 2001), and recalculated carbon fractions in woody debris

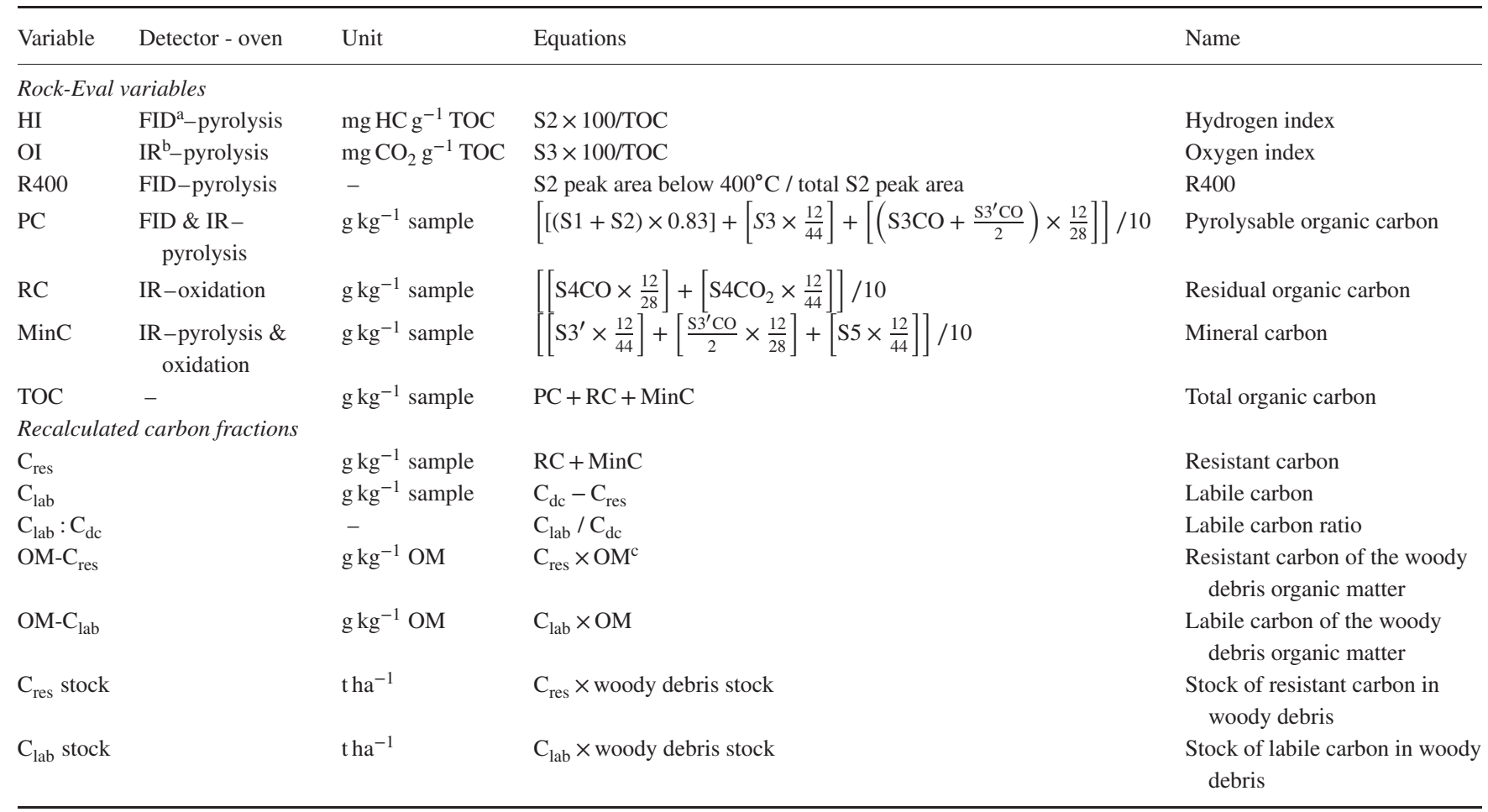

${ }^{a}$ Flame ionization detector.

${ }^{\mathrm{b}}$ Infrared.

${ }^{\mathrm{c}}$ Organic matter $(\mathrm{OM})$ content of woody debris, measured by loss on ignition.

Components recorded during pyrolysis stage: $\mathrm{S} 1$, free hydrocarbons; $\mathrm{S} 2$, hydrocarbons; $\mathrm{S} 3$, organic $\mathrm{CO}_{2} ; \mathrm{S}^{\prime}$, mineral $\mathrm{CO}_{2} ; \mathrm{S} 3 \mathrm{CO}$, organic $\mathrm{CO} ; \mathrm{S} 3^{\prime} \mathrm{CO}$, organic and mineral $\mathrm{CO}$.

Components recorded during oxidation stage: $\mathrm{S}_{4} \mathrm{CO}_{2}$, organic $\mathrm{CO}_{2} ; \mathrm{S} 4 \mathrm{CO}$, organic $\mathrm{CO} ; \mathrm{S} 5$, mineral $\mathrm{CO}_{2}$.

Table 3 summarizes the variables obtained from pyrolysis and the carbon fractions determined from it. Here, we used six variables from the pyrolysis that express the degree of transformation and humification of organic matter (Disnar et al., 2003): (i) HI (hydrogen index); (ii) OI (oxygen index); (iii) R400, the portion of the $\mathrm{S} 2$ signal below $400^{\circ} \mathrm{C}$; (iv) pyrolysable carbon (PC), the amount of organic carbon released during the pyrolysis stage; (v) residual organic carbon (RC), the amount of organic carbon released during the oxidation stage and (vi) mineral carbon (MinC), the amount of carbon released at the end of pyrolysis and oxidation.

We assumed that the soil and woody debris contained no free carbonate although the soil was limed. The amount of inorganic carbon added by liming did not exceed $0.60 \mathrm{tha}^{-1}$ between October 2008 and November 2011, whereas the organic carbon stock was $61.2 \mathrm{tha}^{-1}$ at $0-30-\mathrm{cm}$ depth under forest (Perrin etal., 2014). Liming increased the soil's $\mathrm{pH}$, but it remained acid for 3 years after cultivation; it was less than 5.6 at $0-5-\mathrm{cm}$ depth (Figure 1). The powdered dolomite applied was readily dissolved in the soil. We therefore disregarded inorganic carbon, and assumed that all the carbon compounds from RE analysis had an organic origin, including MinC. Woody debris contained small contents of MinC, ranging from 0.60 to $2.17 \%$, with a similar magnitude of plant

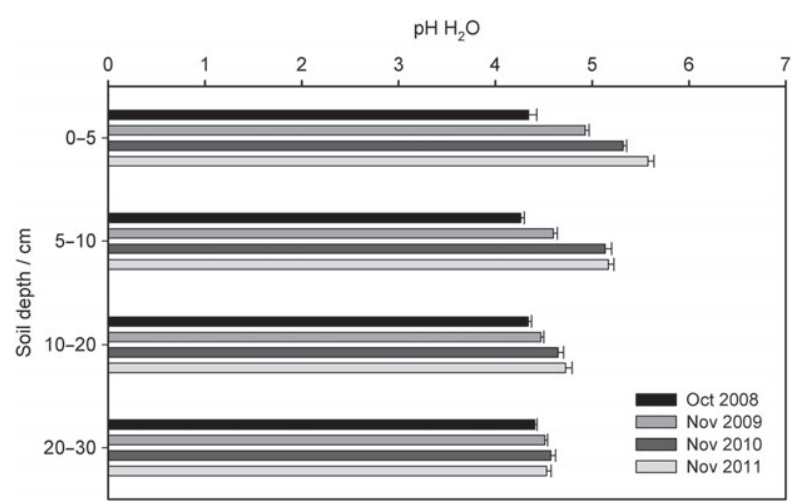

Figure 1 Soil pH in forest soil (October 2008) and after cultivation (without taking account of the cropping system). Error bars represent standard errors ( $n=17$ for October 2008, $n=72$ for November 2009, $n=12$ for November 2010 and November 2011). Soil $:$ water ratio $=1: 2.5$.

and litter samples to that reported by Volland-Tuduri (2005) in the Cerrados (Brazil).

From the RE pyrolysis we determined: (i) a resistant carbon pool as $\mathrm{C}_{\mathrm{res}}=\mathrm{RC}+\mathrm{MinC}$ and (ii) a labile carbon pool as $\mathrm{C}_{\mathrm{lab}}=\mathrm{C}_{\mathrm{dc}}-\mathrm{C}_{\mathrm{res}}$. In RE pyrolysis, the response of the FID detector 


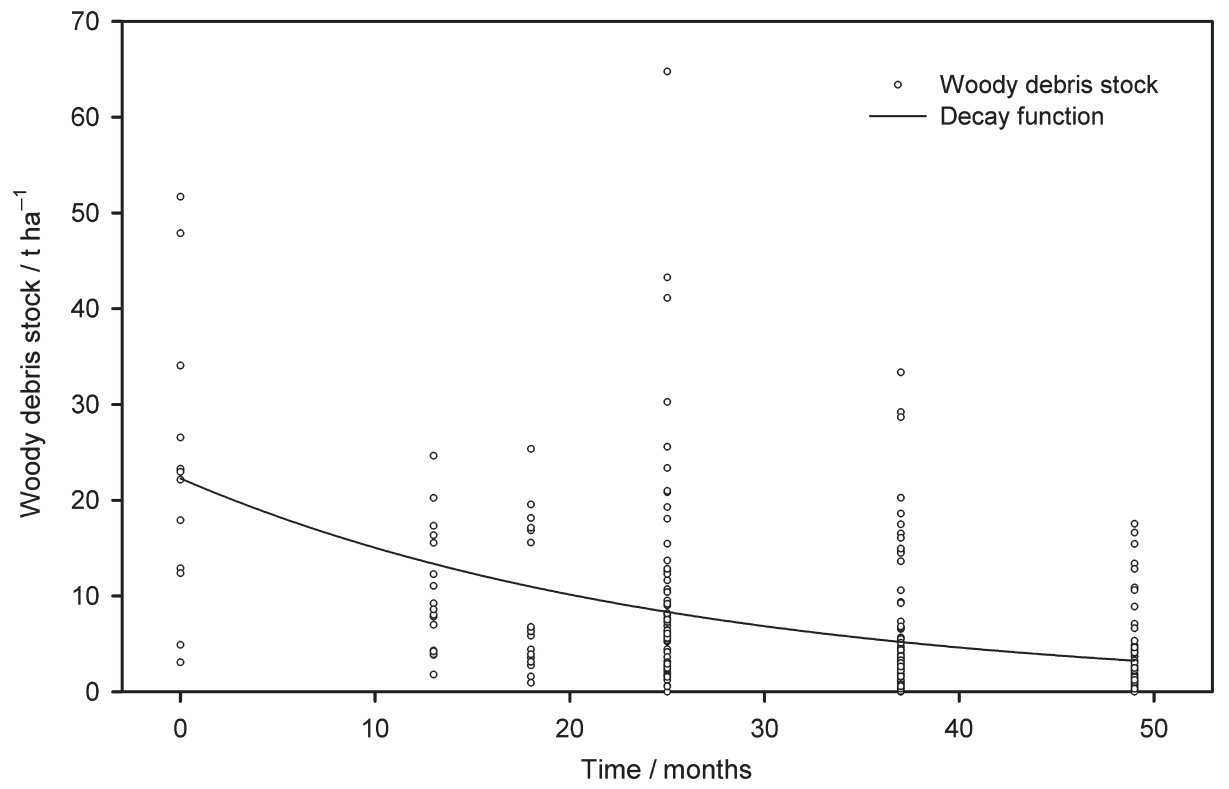

Figure 2 Estimated stock of woody debris $>4 \mathrm{~mm}$ plotted against time at $0-30-\mathrm{cm}$ depth in the soil profile in $\mathrm{t} \mathrm{ha}^{-1}$. The decay model is $y=22.3 \times e^{(-0.039 t)}$.

during the pyrolysis stage (corresponding to the S2 pyrogram and considered as part of the pyrolysable carbon) is small for cellulose and polysaccharides, which explains why $\mathrm{C}_{\mathrm{dc}}$ (carbon contents determined by dry combustion) are larger than TOC contents, especially for plant materials and litter horizons (Disnar etal., 2003). We must assume therefore, that pyrolysable carbon (PC) content is underestimated. We attributed this difference in carbon between $\mathrm{C}_{\mathrm{dc}}$ and TOC to the labile carbon pool. We also determined OM- $\mathrm{C}_{\text {lab }}$ and $\mathrm{OM}-\mathrm{C}_{\text {res }}$ by relating $\mathrm{C}_{\mathrm{lab}}$ and $\mathrm{C}_{\mathrm{res}}$ to the OM content of woody debris.

\section{Statistical analysis}

We fitted a non-linear curve to the woody debris stock for the 4 years after deforestation to represent the decay process. We analysed the full dataset without taking into account the blocks and the crop systems because they had no significant effect $(P<0.05)$ on the woody debris stock over time (comparison of the mean for each sampling date with the Kruskal-Wallis test, data not shown). For Rock-Eval variables determined on woody debris (Table 3), means were compared for different sampling dates with the analysis of variance (ANOVA). The null hypothesis tested was that there was no difference between the means of each variable for the six sampling dates. We checked the normality and homoscedasticity of residuals for each ANOVA. None of the variables was transformed. Statistical analysis was done with $\mathrm{R}$ version 2.15.2.

\section{Results}

\section{Mass loss of woody debris}

Woody debris remaining on the soil after deforestation in October 2008 , considered to be $>4 \mathrm{~mm}$, was estimated as $24.1 \pm 3.8 \mathrm{tha}^{-1}$.
After deforestation, the stock of woody debris $>4 \mathrm{~mm}$ decreased quickly to a final estimate of $3.1 \pm 0.5 \mathrm{tha}^{-1}$ in November 2012 (Figure 2 and Table 4). The mass loss followed an exponential decay of the form:

$$
y=22.3 \times e^{-0.039 t},
$$

where $y$ is the woody debris stock in $\mathrm{tha}^{-1}$ and $t$ is the time in months since deforestation. The half-life of woody debris $>4 \mathrm{~mm}$ was 17.6 months. Mean residence time (MRT) of woody debris was 25.5 months. The woody debris biomass was still heterogeneous after 25 months (November 2010), but the sample size $(n=72)$ explains the smaller standard error compared with those for November 2009 and April 2010 (Table 4).

\section{Carbon, nitrogen and organic matter content in woody debris}

The carbon content of the woody debris decreased with time (Table 4). The carbon stock of the woody debris followed the same trend as the biomass loss, with $11.2 \pm 1.9 \mathrm{t} \mathrm{ha}^{-1}$ in October 2008 and $1.2 \pm 0.2 \mathrm{tha}^{-1}$ in November 2012. The $\mathrm{C}: \mathrm{N}$ ratio was $108.5 \pm 8.9$ at the beginning of the experiment; it decreased to $39.0 \pm 4.2$ in November 2009 and then stabilized. The organic matter content of woody debris (measured by loss on ignition) was $938 \pm 16 \mathrm{~g} \mathrm{~kg}^{-1}$ in October 2008 and decreased to $778 \pm 17 \mathrm{~g} \mathrm{~kg}^{-1} 3$ years after deforestation.

\section{Organic matter composition assessed by Rock-Eval pyrolysis}

Characterization of organic matter in woody debris samples by Rock-Eval pyrolysis gave the following results:

1. The hydrogen index (HI) decreased significantly $(F=18.04, P<$ 0.0001 , Table 5) from October $2008\left(486 \pm 4 \mathrm{mg} \mathrm{HC} \mathrm{g}^{-1} \mathrm{TOC}\right)$ 
Table 4 Biomass, carbon content and stocks, organic matter (OM), Rock-Eval variables and recalculated carbon fractions of woody debris over time

\begin{tabular}{|c|c|c|c|c|c|c|c|c|c|c|c|c|}
\hline Time & \multicolumn{5}{|c|}{ Conventional OM properties } & \multicolumn{7}{|c|}{ Values and carbon fractions from Rock-Eval pyrolysis } \\
\hline $\begin{array}{c}\text { October } 2008 \\
0 \text { months }\end{array}$ & $\begin{array}{l}24.1 \\
(3.8)\end{array}$ & $\begin{array}{r}465 \\
(6)\end{array}$ & $\begin{array}{l}11.2 \\
(1.9)\end{array}$ & $\begin{array}{r}108.5 \\
(8.9)\end{array}$ & $\begin{array}{l}938 \\
(16)\end{array}$ & $\begin{array}{r}486 \\
(4)\end{array}$ & $\begin{array}{r}182 \\
(2)\end{array}$ & $\begin{array}{c}0.76 \\
(0.01)\end{array}$ & $\begin{array}{r}370 \\
(7)\end{array}$ & $\begin{array}{r}296 \\
(4)\end{array}$ & $\begin{array}{r}201 \\
(3)\end{array}$ & $\begin{array}{c}0.60 \\
(0.01)\end{array}$ \\
\hline $\begin{array}{c}\text { November } 2009 \\
13 \text { months }\end{array}$ & $\begin{array}{l}10.2 \\
(1.5)\end{array}$ & $\begin{array}{r}438 \\
(10)\end{array}$ & $\begin{array}{c}4.5 \\
(0.8)\end{array}$ & $\begin{array}{l}39.0 \\
(4.2)\end{array}$ & $\begin{array}{l}877 \\
(20)\end{array}$ & $\begin{array}{l}389 \\
(33)\end{array}$ & $\begin{array}{r}178 \\
(5)\end{array}$ & $\begin{array}{c}0.66 \\
(0.02)\end{array}$ & $\begin{array}{r}375 \\
(9)\end{array}$ & $\begin{array}{r}241 \\
(14)\end{array}$ & $\begin{array}{l}258 \\
(16)\end{array}$ & $\begin{array}{c}0.48 \\
(0.03)\end{array}$ \\
\hline $\begin{array}{l}\text { April } 2010 \\
18 \text { months }\end{array}$ & $\begin{array}{c}9.2 \\
(1.8)\end{array}$ & $\begin{array}{l}429 \\
(16)\end{array}$ & $\begin{array}{c}3.9 \\
(0.9)\end{array}$ & $\begin{array}{l}42.1 \\
(3.3)\end{array}$ & $\begin{array}{l}849 \\
(26)\end{array}$ & $\begin{array}{r}398 \\
(17)\end{array}$ & $\begin{array}{l}167 \\
(10)\end{array}$ & $\begin{array}{c}0.70 \\
(0.04)\end{array}$ & $\begin{array}{l}373 \\
(17)\end{array}$ & $\begin{array}{r}245 \\
(9)\end{array}$ & $\begin{array}{l}261 \\
(14)\end{array}$ & $\begin{array}{c}0.49 \\
(0.02)\end{array}$ \\
\hline $\begin{array}{l}\text { November } 2010 \\
25 \text { months }\end{array}$ & $\begin{array}{c}8.9 \\
(1.3)\end{array}$ & $\begin{array}{l}430 \\
(16)\end{array}$ & $\begin{array}{c}3.8 \\
(0.7)\end{array}$ & $\begin{array}{c}45.2 \\
(4.7)\end{array}$ & $\begin{array}{l}869 \\
(26)\end{array}$ & $\begin{array}{l}388 \\
(17)\end{array}$ & $\begin{array}{r}179 \\
(10)\end{array}$ & $\begin{array}{c}0.72 \\
(0.01)\end{array}$ & $\begin{array}{l}369 \\
(13)\end{array}$ & $\begin{array}{r}240 \\
(8)\end{array}$ & $\begin{array}{r}254 \\
(5)\end{array}$ & $\begin{array}{c}0.49 \\
(0.01)\end{array}$ \\
\hline $\begin{array}{l}\text { November } 2011 \\
37 \text { months }\end{array}$ & $\begin{array}{c}5.9 \\
(0.8)\end{array}$ & $\begin{array}{l}387 \\
(10)\end{array}$ & $\begin{array}{c}2.3 \\
(0.4)\end{array}$ & $\begin{array}{l}35.0 \\
(1.9)\end{array}$ & $\begin{array}{l}778 \\
(17)\end{array}$ & $\begin{array}{r}337 \\
(14)\end{array}$ & $\begin{array}{r}180 \\
(5)\end{array}$ & $\begin{array}{c}0.66 \\
(0.01)\end{array}$ & $\begin{array}{l}338 \\
(11)\end{array}$ & $\begin{array}{r}218 \\
(7)\end{array}$ & $\begin{array}{r}280 \\
(9)\end{array}$ & $\begin{array}{c}0.44 \\
(0.02)\end{array}$ \\
\hline
\end{tabular}

Values are means followed in parentheses by standard errors. Biomass and carbon stock were measured from woody debris sorted into soil samples $(n=14$ in October 2008, $n=18$ in November 2009 and April 2010, $n=72$ in November 2010, November 2011 and November 2012). Chemical and Rock-Eval values were measured on woody samples selected randomly from the whole set of woody debris available at each date $(n=12$ in October 2008 and $n=6$ for other sampling dates).

Table 5 Results of the ANOva to test the effect of sampling date of woody debris on the Rock-Eval variables

\begin{tabular}{|c|c|c|c|c|c|c|}
\hline Variable & Source & Degrees of freedom & Sum of squares & Mean square & F-value & $P$-value \\
\hline $\mathrm{HI}$ & Residuals & 36 & 58312 & 1620 & & \\
\hline OI & Residuals & 36 & 14232 & 395.3 & & \\
\hline \multirow[t]{2}{*}{ R400 } & Dates & 5 & 0.0786 & 0.0157 & 6.56 & 0.0002 \\
\hline & Residuals & 36 & 0.0863 & 0.0024 & & \\
\hline \multirow[t]{2}{*}{ OM-Clab } & Dates & 5 & 447.3 & 89.46 & 21.65 & $<0.0001$ \\
\hline & Residuals & 36 & 148.7 & 4.13 & & \\
\hline \multirow[t]{2}{*}{ OM-Cres } & Dates & 5 & 394.1 & 78.82 & 15.31 & $<0.0001$ \\
\hline & Residuals & 36 & 185.3 & 5.15 & & \\
\hline \multirow[t]{2}{*}{ Clab:Cdc } & Dates & 5 & 0.1674 & 0.0335 & 20.09 & $<0.0001$ \\
\hline & Residuals & 36 & 0.0560 & 0.0017 & & \\
\hline
\end{tabular}

See Table 2 for the number of samples.

to November $2012\left(328 \pm 12 \mathrm{mg} \mathrm{HC} \mathrm{g}^{-1}\right.$ TOC) (Table 4). The value of $\mathrm{R} 400$ also decreased from $0.75 \pm 0.01$ to $0.66 \pm 0.02$ one year after deforestation, but it did not change from November 2009 to November 2012 (Table 4). The decrease in R400 after deforestation is due to the decrease in S2 signal intensity before $400^{\circ} \mathrm{C}$, rather than an increase in $\mathrm{S} 2$ after $400^{\circ} \mathrm{C}$ in decomposed woody debris (Figure 3).

2. The oxygen index (OI) did not change significantly with time $(F=1.813, \quad P=0.135$, Table 5); it ranged from $167 \pm 10 \mathrm{mgCO}_{2} \mathrm{~g}^{-1}$ TOC in April 2010 to $200 \pm 14 \mathrm{mg} \mathrm{CO}_{2} \mathrm{~g}^{-1}$ TOC in November 2012 (Table 4).

The total organic carbon (TOC) contents of woody debris measured by RE pyrolysis did not change significantly $(F=2.282$, $P=0.0669$, Table 5), with values from $338 \pm 11 \mathrm{~g} \mathrm{~kg}^{-1}$ in November 2011 to $375 \pm 9 \mathrm{~g} \mathrm{~kg}^{-1}$ in November 2009 (Table 4).
The TOC contents were less than the carbon contents measured by dry combustion $\left(\mathrm{C}_{\mathrm{dc}}\right)$. Linear regression between TOC and $\mathrm{C}_{\mathrm{dc}}$ gave:

$$
C_{d c}=9.8+0.62 \times T O C
$$

with $R^{2}=0.69(P<0.0001)$.

3. Labile carbon in the organic matter of woody debris $\left(\mathrm{OM}-\mathrm{C}_{\mathrm{lab}}\right)$ was $296 \pm 4 \mathrm{~g} \mathrm{~kg}^{-1}$ in October 2008, and decreased significantly with time $\left(F=21.65, P<0.0001\right.$, Table 5) to $205 \pm 7 \mathrm{~g} \mathrm{~kg}^{-1}$ in November 2012 (Table 4). On the other hand, resistant carbon in organic matter $\left(\mathrm{OM}-\mathrm{C}_{\mathrm{res}}\right)$ increased significantly $(F=15.31$, $P<0.0001$, Table 5) after deforestation from $201 \pm 3 \mathrm{~g} \mathrm{~kg}^{-1}$ in October 2008 to more than $250 \mathrm{~g} \mathrm{~kg}^{-1}$ after November 2009 . 


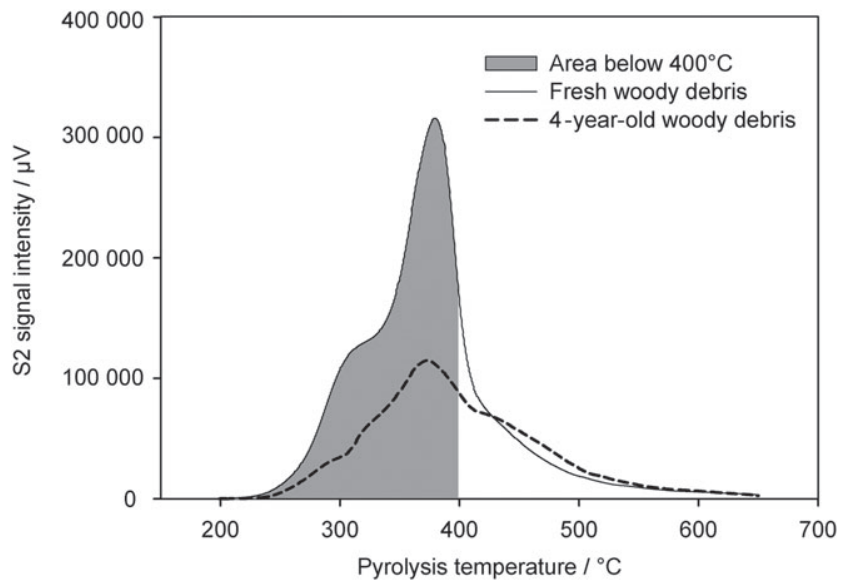

Figure 3 The S2 pyrogram of Rock-Eval pyrolysis for fresh woody debris and for a 4-year-old woody debris sample. R400 is the ratio between area below $400^{\circ} \mathrm{C}$ and total area.

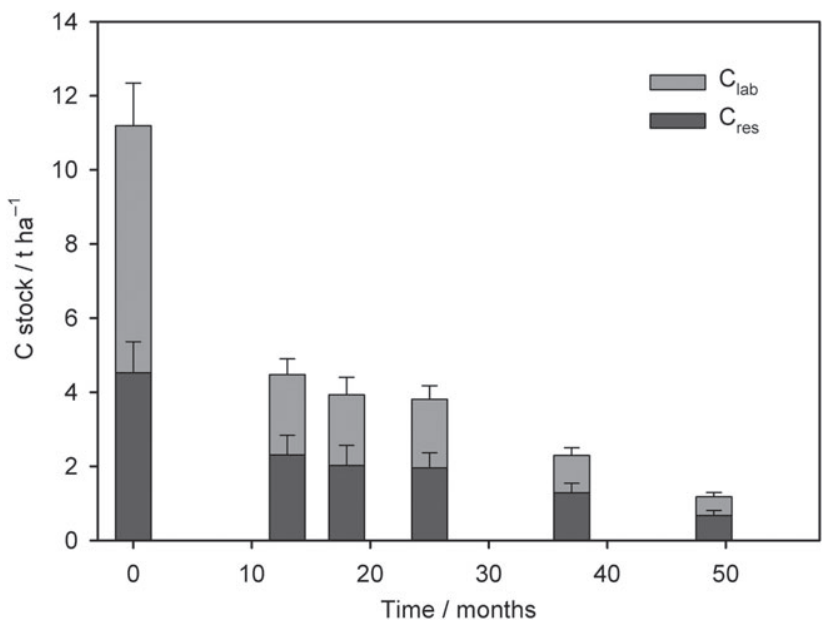

Figure 4 Stock of labile carbon pool $\left(\mathrm{C}_{\text {lab }}\right)$ and resistant carbon pool $\left(\mathrm{C}_{\text {res }}\right)$ of woody debris $>4 \mathrm{~mm}$ in the $0-30$-cm layer. Values are means, error bars represent standard errors ( $n=14$ at the beginning of the experiment, $n=18$ at the 13th and 18th months, $n=72$ at the 25th, 37th and 49th months). See Table 3 for the calculation of variables.

4. The $\mathrm{C}_{\text {lab }}$ and $\mathrm{C}_{\text {res }}$ stocks decreased over time (Figure 4), but decomposition of $\mathrm{C}_{\text {lab }}$ was faster:

$$
\begin{aligned}
& C_{\mathrm{lab}}=6.2 \times e^{-0.054 t}, \\
& C_{\mathrm{res}}=4.3 \times e^{-0.035 t},
\end{aligned}
$$

where $t$ is the time in months and carbon stocks are expressed in tha ${ }^{-1}$. The half-lives of $\mathrm{C}_{\text {lab }}$ and $\mathrm{C}_{\text {res }}$ were 12.9 and 19.9 months, respectively. Furthermore, the $\mathrm{C}_{\text {lab }}: \mathrm{C}_{\mathrm{dc}}$ ratio was $0.60 \pm 0.01$ in October 2008 and decreased to 0.50 after November 2009 (Table 4).

\section{Discussion}

\section{Kinetics of woody debris mass loss}

The first-order decay, describing the mass loss of woody debris (Figure 2), is commonly used to describe the decomposition of soil organic matter (Six \& Jastrow, 2002). In Senegal (with a dry and sub-humid climate), Manlay et al. (2004) observed a greater rate of decay for woody roots buried in the soil, but in their study the roots were smaller $(<10 \mathrm{~mm})$ than the woody debris in our study, especially in the first year after spreading the debris. Other research on the decomposition of dead wood in the Amazonian forest reported slower rates of decay than for our study, with a half-life of 4.1 years (Chambers et al., 2000) and with a range of 2.3-14 years (excluding pioneer species, assumed to be absent in our work) (Hérault et al., 2010). Our results showed that smaller debris buried in deforested soil had greater rates of decomposition, with a half-life of 17.6 months. Such a result might be expected because of the larger size of debris in the forest studies, which reduces the surface area for weathering and biological activities, especially microbial degradation. Furthermore, decomposition processes might be accelerated after deforestation because of the increase in soil temperature (Nascimento \& Laurance, 2004).

At the experimental site, the annual soil temperature at $10-\mathrm{cm}$ depth ranges from 24.7 to $26.0^{\circ} \mathrm{C}$ in the forest and from 24.6 to $32.6^{\circ} \mathrm{C}$ in cultivated plots (Petitjean, 2013). On the same date, the temperature difference between forest and cultivated plots can reach $8^{\circ} \mathrm{C}$ (Petitjean, 2013). Furthermore, on cultivated land solar radiation can reach the topsoil surface directly (Van Wambeke, 1992). This increase in temperature in cultivated soil could accelerate mineralization, although the effect of temperature above $30^{\circ} \mathrm{C}$ on mineralization remains unclear (Paul, 2001). Soil moisture conditions are also favourable to microbial and fungal activity because the soil is moist and never waterlogged. White-rot fungi were observed under the litter layer after deforestation, but termite activity was not observed. The large variation in decay patterns can be explained by the numerous species of trees before deforestation and by the spatial variation in the woody debris that was spread during deforestation. We found a wide range of C:N ratios in fresh woody debris (Table 4), which reflects tree diversity, the nature of wood and plant phonological stage. In the Paracou forest, within $10 \mathrm{~km}$ of our study site, Hérault et al. (2010) showed that variation in wood density was large, from 0.46 to $1.24 \mathrm{~g} \mathrm{~cm}^{-3}$ (again excluding pioneer species), and that rates of decay of dead wood depended on wood density. The mass loss of woody debris did not depend on the cropping system, but mainly on the general soil and climatic conditions because of the short time period studied and the large variation in the rate of decay of woody debris. Furthermore, the largest mass loss occurred during the first year after deforestation before the three crop systems were established in December 2009. During this first year the soil was under the same cover crops (Perrin et al., 2014).

We found only one study in a similar climatic area where the mass of wood mulch was measured after deforestation and after the establishment of land for cropping. Davidson et al. (2008) 
found that carbon stock from the litter layer in a 'chop-and-mulch' crop system was $17.7 \pm 0.4 \mathrm{tha}^{-1}$ immediately after the input of woody mulch and $1.9 \pm 0.3 \mathrm{tha}^{-1}$ after 34 months of cultivation, whereas we observed a decrease in carbon stock from woody debris of $11.2 \pm 1.9$ to $2.3 \pm 0.4 \mathrm{tha}^{-1}$ after 37 months of cultivation. The rate of decomposition of woody mulch in the study by Davidson et al. (2008) appears to be faster than that in our study. However, Davidson et al. (2008) did not report the size of debris, and the soil of their site was not tilled after deforestation or before cultivation, whereas the converse was true for our study. The comparison of these two studies emphasizes the need for further research to test the effect of burying woody debris on its decay.

The decomposition of woody debris contributed to total soil organic carbon stock through a fragmentation process because the mass loss of woody debris was not completely converted into $\mathrm{CO}_{2}$ by mineralization. On the same experimental site in November 2009 and April 2010 we observed more soil organic carbon in the soil fraction $<2 \mathrm{~mm}$ of cultivated plots than that of the forest (Perrin etal., 2014). Figure 5 shows that a large part of the woody debris and other carbon inputs from deforestation (forest litter and coarse forest roots) were fragmented finely during their decomposition, which explains the increase in carbon in the soil fraction $<2 \mathrm{~mm}$ and in other plant debris $>2 \mathrm{~mm}$ up to 18 months after deforestation. Nevertheless, carbon that was freshly incorporated into the soil was probably mineralized rapidly because we observed a large decrease in soil carbon in the fraction $<2 \mathrm{~mm}$ between 18 and 25 months (April-October 2010) after deforestation (Perrin et al., 2014). Further research is required to assess the proportion of carbon in soil that is lost as $\mathrm{CO}_{2}$ or dissolved organic carbon, and the proportion of carbon incorporated into the soil.

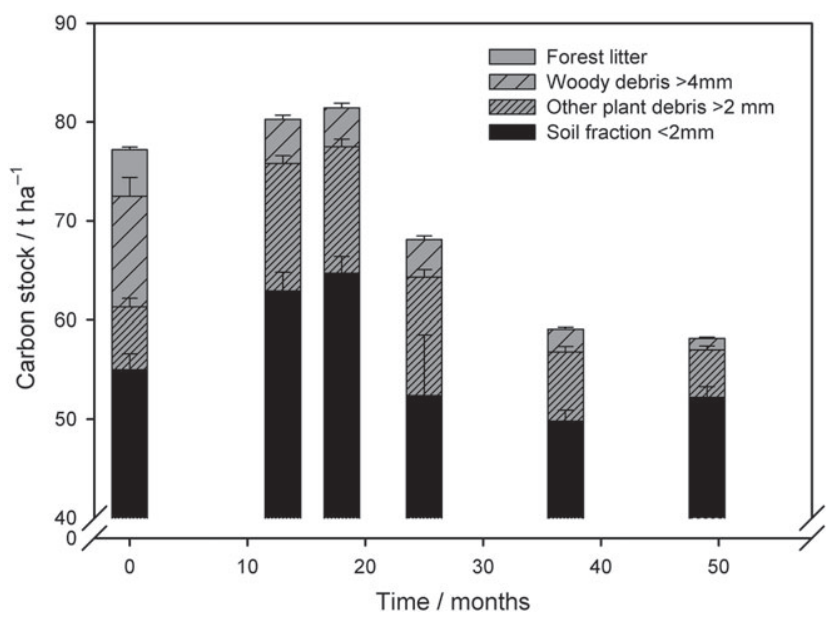

Figure 5 Carbon stocks in forest litter, woody debris $>4 \mathrm{~mm}$, other plant debris $>2 \mathrm{~mm}$ and soil fraction $<2 \mathrm{~mm}$ at deforestation and in cultivated soil. Values are means, error bars represent standard errors ( $n=17$ at deforestation and $n=72$ in cultivated soil for other plant debris $>2 \mathrm{~mm}$ and soil fraction $<2 \mathrm{~mm}$ ), calculated from the data of Perrin et al. (2014).
Organic matter transformation during the decomposition of woody debris

The organic geochemistry of woody debris evolved quickly during its decomposition in soil, as attested by the decrease in the $\mathrm{C}: \mathrm{N}$ ratio, Rock-Eval $\mathrm{HI}$ and $\mathrm{R} 400$, and $\mathrm{OM}-\mathrm{C}_{\mathrm{lab}}$ one year after deforestation. In parallel, OM- $\mathrm{C}_{\text {res }}$ increased during the first year of the experiment (Table 3). Decarboxylation, dehydrogenation and mineralization of labile components occurred after the spreading and burial of woody debris. A decrease in the $\mathrm{C}: \mathrm{N}$ ratio during decomposition has been observed also for woody roots (Manlay et al., 2004) and for woody debris (Mackensen \& Bauhus, 2003; Olajuyigbe et al., 2011).

With Rock-Eval pyrolysis, Disnar etal. (2003) observed that the hydrogen index (HI) decreased from top to bottom in the litter horizons. In other words, HI decreases as organic matter is transformed biochemically by biodegradation. The same process can explain the decrease in R400 after burial of woody debris; compounds such as hemicellulose, cellulose and slightly-oxidized lignin (fresh and labile organic matter) are pyrolysed mostly below $400^{\circ} \mathrm{C}$, whereas complex and more stable organic matter is pyrolysed above $400^{\circ} \mathrm{C}$ (Disnar et al., 2003). Therefore, R400 can be considered as an indicator of humification or organic matter transformation or stabilization, or both (Disnar et al., 2008; Gogo etal., 2011). In our case, R400 showed slight humification only of woody debris, mostly during the first year of the experiment. The oxygen index (OI) did not change in our experiment (Table 4), whereas we might have expected an increase related to oxygen enrichment during humification (Disnar et al., 2003). Oxidation in our case did not play a major role in transformation of the wood. The oxygen index indicates either the oxygenated character of the organic matter according to its origin or is associated with the physico-chemical oxidation of organic matter over time. In the case of organic matter preservation OI decreases, but during humification OI generally increases because of oxidative alteration and polymerization. In our case the stability of OI and decrease in HI can be attributed to the humid tropical climate, which promotes the degradation of woody debris by fungi and bacteria with little humification.

The changes in $\mathrm{C}: \mathrm{N}$ ratio and $\mathrm{R} 400$ show that decarboxyation, dehydrogenation and humification occurred mainly in the first year after the spreading of woody debris. The HI and OM- $\mathrm{C}_{\text {lab }}$, however, continued to change after the first year of the experiment (Table 4), showing that decomposition of woody debris was progressive. Consequently, $\mathrm{C}_{\text {lab }}$ and $\mathrm{C}_{\text {res }}$ decreased with time, so there was neither long-term biochemical preservation nor polymerization of organic matter in the form of woody debris (Figure 4). This absence of organic matter preservation in woody debris and lack of humification over time accords with first-order decay for mass loss of woody debris. The decrease in the $\mathrm{C}_{\mathrm{lab}}: \mathrm{C}_{\mathrm{dc}}$ ratio occurred during the first year only after deforestation (Table 4). The quantity of $\mathrm{C}_{\text {res }}$ represents the carbon pool that is initially resistant, but its decomposition with time might produce labile biochemical compounds that could be pyrolysed and identified as $\mathrm{C}_{\mathrm{lab}}$. 
Rock-Eval pyrolysis as a tool to assess the fate of OM in soils

Rock-Eval Pyrolysis is a simple method that enables us to (i) assess the chemical transformation of woody debris during its decomposition and (ii) distinguish two carbon pools with different responses to decomposition. The changes in the organic geochemistry of plant residue determined by Rock-Eval pyrolysis were more gradual than those of the C:N ratio (Table 4). The relationship between $\mathrm{R} 400$ and the $\mathrm{C}: \mathrm{N}$ ratio confirms the value of $\mathrm{R} 400$ for assessing the humification of fresh organic matter (Figure 6) during its decomposition. One year after deforestation (decomposed woody debris), R400 was correlated with C:N $(r=0.61, P<0.001, n=30)$. Fresh woody debris sampled in October 2008 showed a wide range of C:N ratios, but little variation in $\mathrm{R} 400$ (Figure 6). The wide range of $\mathrm{C}: \mathrm{N}$ ratios can be explained by the large number of woody species that were shredded during deforestation and that have different nitrogen contents. However, nitrogen content does not affect the proportions of hemicellulose, cellulose and lignin compounds, which are pyrolysed mainly below $400^{\circ} \mathrm{C}$ and explain the lack of variation in R400 for woody debris in October 2008 ('fresh woody debris' in Figure 6).

The novelty of this study is that we did not focus on only HI, OI and R400. These properties are obtained from the pyrolysis stage and are the most discussed in soil organic matter studies (Disnar et al., 2003; Sebag et al., 2006; Carrie et al., 2012). Other Rock-Eval properties, such as $\mathrm{OM}-\mathrm{C}_{\mathrm{lab}}$ and $\mathrm{OM}-\mathrm{C}_{\text {res }}$, also showed the transformation of woody debris. More attention should be given to the carbon released during oxidation and at the end of pyrolysis, which corresponds to the $\mathrm{OM}-\mathrm{C}_{\mathrm{res}}$ pool. We showed that this pool might represent more than $50 \%$ of the organic matter in woody debris one year after deforestation. Finally, use of Rock-Eval pyroloysis for the determination of carbon stocks in woody debris enabled the absolute amount of labile and resistant carbon and their half-lives, corresponding to the $\mathrm{C}_{\mathrm{lab}}$ and $\mathrm{C}_{\text {res }}$ pools, to be monitored over time (Figure 6). The $\mathrm{C}_{\text {lab }}$ and $\mathrm{C}_{\text {res }}$ values highlight the lack of preservation and humification of organic matter in the woody

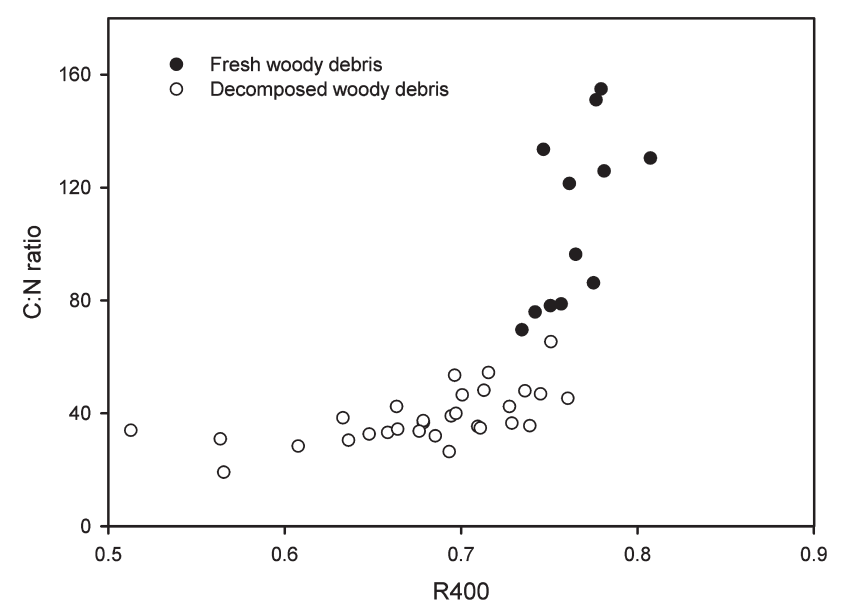

Figure 6 Scatter diagrams of C:N ratio against R400 (portion of the S2 signal below $400^{\circ} \mathrm{C}$ ) for woody debris $>4 \mathrm{~mm}$. debris. However, we could not link carbon pools that we determined in this study directly to classic organic compounds (soluble carbon, sugars, cellulose, lignins and waxes). Deconvolution of the S2 pyrogram can be used to discriminate between different organic constituents (Sebag et al., 2006), but this approach might be limited for materials rich in cellulose and lignin. The latter have a similar maximum temperature to that of the $\mathrm{S} 2$ peak, and furthermore the lignin S2 peak is wide (Disnar et al., 2003).

For studies of woody debris with Rock-Eval pyrolysis we suggest the following: (i) consider that the 'MinC' fraction is an organic fraction and group it with the $\mathrm{RC}$ fraction to form the $\mathrm{C}_{\text {res }}$ pool and (ii) measure organic matter content and $\mathrm{C}_{\mathrm{dc}}$ (carbon content measured by dry combustion). This enables two carbon pools, $\mathrm{C}_{\text {lab }}$ and $\mathrm{C}_{\text {res }}$, to be determined that respond to decomposition and humification, and whose evolution over time can be compared for a given amount of organic matter.

\section{Conclusions}

Decomposition of woody debris in a deforested and cultivated soil in a humid tropical climate was rapid, with a half-life of only 17.6 months, and was characterized by a first-order function. This decay is faster than that reported for coarser woody debris in forest ecosystems because of the smaller size of the debris and the hotter conditions in this study.

Rock-Eval pyrolysis enabled the overall organic geochemistry of the decomposition of woody debris to be studied, and it showed that it changed rapidly with time. After burial, woody debris was more thermally resistant and the proportion of labile carbon decreased. However, there was little humification and even the resistant carbon pool decreased during the 4 years of our study, in accord with first-order decay of the debris. Our study shows that the benefits of amending the soil with woody debris to create soil carbon occur only during the first year after deforestation because of its rapid decomposition.

\section{Acknowledgements}

This study was funded by the Fond Européen de Développement Régional, the CETIOM (Centre Technique Interprofessionnel des Oléagineux et du Chanvre) and the Guiana Region. K. Fujisaki was funded by an ANRT (Agence Nationale de la Recherche Technologique) project CIFRE ANRT-CETIOM N²011/1036. We thank Bernard Garric and Jean-Claude Horth for their help in the field, and Rachel Boscardin for her assistance with Rock-Eval analysis. We also thank Jean-Robert Disnar for his advice on Rock-Eval pyrolysis and Martial Bernoux for his comments on the English revision by Alan Scaife.

\section{References}

AFES 2009. Référentiel pédologique. Editions Quae. Association Française pour l'Etude du Sol, Versailles.

Almendros, G. 2008. Carbon sequestration in soil. In: Encyclopedia of Soil Science (ed W. Chesworth), pp. 97-99. Springer, Dordrecht. 
Andreux, F. \& Meunier-Lamy, I. 1994. Génèse et propriétés des molécules humiques. In: Pédologie 2: Constituants et propriétés du sol (eds P. Duchaufour \& B. Souchier), pp. 109-134. Masson, Paris.

Barthès, B., Manlay, R. \& Porte, O. 2010. Effets de l'apport de bois raméal sur la plante et le sol: une revue des résultats expérimentaux. Cahiers Agricultures, 19, 280-287.

Behar, F., Beaumont, V. \& Penteado, H.D.B. 2001. Rock-Eval 6 technology: performances and developments. Oil \& Gas Science and Technology, 56, $111-134$

Carrie, J., Sanei, H. \& Stern, G. 2012. Standardisation of Rock-Eval pyrolysis for the analysis of recent sediments and soils. Organic Geochemistry, 46, 38-53.

Cerri, C.C. \& Volkoff, B. 1987. Carbon content in a yellow latosol of central Amazon rain forest. Acta Oecologica. Oecologia Generalis, 8 , $29-42$.

Chambers, J.Q., Higuchi, N., Schimel, J.P., Ferreira, L.V. \& Melack, J.M. 2000. Decomposition and carbon cycling of dead trees in tropical forests of the central Amazon. Oecologia, 122, 380-388.

Comte, I., Davidson, R., Lucotte, M., de Carvalho, C.J.R., de Assis Oliveira, F., da Silva, B.P. et al. 2012. Physicochemical properties of soils in the Brazilian Amazon following fire-free land preparation and slash-and-burn practices. Agriculture, Ecosystems \& Environment, 156, $108-115$.

Davidson, E.A., De Abreu Sà, T.D., Reis Carvalho, C.J., De Oliveira Figueiredo, R., Kato, M.S.A., Kato, O.R. et al. 2008. An integrated greenhouse gas assessment of an alternative to slash-and-burn agriculture in eastern Amazonia. Global Change Biology, 14, 998-1007.

Delarue, F., Laggoun-Défarge, F., Disnar, J.R., Lottier, N. \& Gogo, S. 2011. Organic matter sources and decay assessment in a Sphagnum-dominated peatland (Le Forbonnet, Jura Mountains, France): impact of moisture conditions. Biogeochemistry, 106, 39-52.

Disnar, J.R., Guillet, B., Keravis, D., Di-Giovanni, C. \& Sebag, D. 2003. Soil organic matter (SOM) characterization by Rock-Eval pyrolysis: scope and limitations. Organic Geochemistry, 34, 327-343.

Disnar, J.-R., Jacob, J., Morched-Issa, M., Lottier, N. \& Arnaud, F. 2008. Assessment of peat quality by molecular and bulk geochemical analysis: application to the Holocene record of the Chautagne marsh (Haute Savoie, France). Chemical Geology, 254, 101-112.

Espitalié, J., Deroo, G. \& Marquis, F. 1985. La pyrolyse Rock-Eval et ses applications. Première partie. Oil \& Gas Science and Technology, 40, 563-579.

Fujisaki, K., Perrin, A.-S., Desjardins, T., Bernoux, M., Balbino, L.C. \& Brossard, M. 2015. From forest to cropland and pasture systems: a critical review of soil organic carbon stocks changes in Amazonia. Global Change Biology, doi: 10.1111/gcb.12906/..

Gogo, S., Laggoun-Défarge, F., Delarue, F. \& Lottier, N. 2011. Invasion of a Sphagnum-peatland by Betula spp and Molinia caerulea impacts organic matter biochemistry. Implications for carbon and nutrient cycling. Biogeochemistry, 106, 53-69.

Hérault, B., Beauchêne, J., Muller, F., Wagner, F., Baraloto, C., Blanc, L. et al. 2010. Modeling decay rates of dead wood in a neotropical forest. Oecologia, 164, 243-251.

IUSS Working Group 2007. World Reference Base for Soil Resources 2006, First Update 2007. World Soil Resources Report No 103, FAO, Rome.
Jobbágy, E.G. \& Jackson, R.B. 2000. The vertical distribution of soil organic carbon and its relation to climate and vegetation. Ecological Applications, 10, 423-436.

Lafargue, E., Marquis, F. \& Pillot, D. 1998. Rock-Eval 6 applications in hydrocarbon exploration, production, and soil contamination studies. Oil \& Gas Science and Technology, 53, 421-437.

Mackensen, J. \& Bauhus, J. 2003. Density loss and respiration rates in coarse woody debris of Pinus radiata, Eucalyptus regnans and Eucalyptus maculata. Soil Biology \& Biochemistry, 35, 177-186.

Manlay, R.J., Masse, D., Chevallier, T., Russell-Smith, A., Friot, D. \& Feller, C. 2004. Post-fallow decomposition of woody roots in the West African savanna. Plant \& Soil, 260, 123-136.

Nascimento, H.E.M. \& Laurance, W.F. 2004. Biomass dynamics in Amazonian forest fragments. Ecological Applications, 14 (Suppl.), S127-S138.

Olajuyigbe, S.O., Tobin, B., Gardiner, P. \& Nieuwenhuis, M. 2011. Stocks and decay dynamics of above- and belowground coarse woody debris in managed Sitka spruce forests in Ireland. Forest Ecology \& Management, 262, 1109-1118.

Pansu, M. \& Gautheyrou, J. 2006. Handbook of Soil Analysis: Mineralogical Organic and Inorganic Methods. Springer, Berlin.

Paul, K. 2001. Temperature and moisture effects on decomposition. In: Net Ecosystem Exchange (eds M.U.F. Kirschbaum \& R. Mueller), pp. 95-102. Cooperative Research Center for Greenhouse Accounting, Canberra.

Perrin, A.-S., Fujisaki, K., Petitjean, C., Sarrazin, M., Godet, M., Garric, B. et al. 2014. Conversion of forest to agriculture in Amazonia with the chop-and-mulch method: does it improve the soil carbon stock? Agriculture, Ecosystems \& Environment, 184, 101-114.

Petitjean, C. 2013. Mesures in situ et simulations des flux de $\mathrm{N}_{2} \mathrm{O}$ émis par les sols. Cas du changement d'usage des terres en Guyane: déforestation par la méthode "chop-and-mulch" suivie de la mise en valeur agricole. Mesures in situ et simulations des flux de $\mathrm{N}_{2} \mathrm{O}$. Thèse de Doctorat, Université des Antilles et de la Guyane, Cayenne.

Powlson, D.S., Whitmore, A.P. \& Goulding, K.W.T. 2011. Soil carbon sequestration to mitigate climate change: a critical re-examination to identify the true and the false. European Journal of Soil Science, 62, $42-55$.

Saenger, A., Cécillon, L., Sebag, D. \& Brun, J.-J. 2013. Soil organic carbon quantity, chemistry and thermal stability in a mountainous landscape: a Rock-Eval pyrolysis survey. Organic Geochemistry, 54, 101-114.

Sebag, D., Disnar, J.R., Guillet, B., Di Giovanni, C., Verrecchia, E.P. \& Durand, A. 2006. Monitoring organic matter dynamics in soil profiles by "Rock-Eval pyrolysis": bulk characterization and quantification of degradation. European Journal of Soil Science, 57, 344-355.

Six, J. \& Jastrow, J.D. 2002. Organic matter turnover. In: Encyclopedia of Soil Science (ed R. Lal), pp. 936-942. Marcel Dekker, New York.

Swift, M.J., Heal, O.W. \& Anderson, J.M. 1979. Decomposition in Terrestrial Ecosystems. Blackwell Press, Oxford.

Van Wambeke, A. 1992. Soils of the Tropics: Properties and Appraisal. McGraw-Hill, New York.

Volland-Tuduri, N. 2005. Nature et mode d'assemblage des constituants minéraux et organiques dans des Ferralsols de la région des Cerrados (Brésil). Evolution après mise en culture. Thèse de Doctorat, Université d'Orléans, Orléans. 